\title{
Well Integrity Management: A Recommendation for Indonesia's Well Life Cycle
}

Ganesha R Darmawan ${ }^{1}$

${ }^{1}$ Department of Petroleum Engineering, Faculty of Design \& Technology, Bandung Institute of Science Technology, Kota Deltamas CBD, Jl. Ganesha Boulevard, Cikarang Pusat, Bekasi, West Java, Indonesia

"Corresponding Author: ganesharinkudarmawan@gmail.com

\begin{tabular}{l}
\hline Article History: \\
Received: October 1, 2020 \\
Receive in Revised Form: November 16, \\
2020 \\
Accepted: November 19, 2020 \\
\hline
\end{tabular}

\section{Keywords:}

methane emissions, well integrity management, well life cycle, well register.

\begin{abstract}
Indonesia oil and gas field mostly are brownfields which were drilled in the late '40s up to '90s. Development and further development of a new structure throughout the years is done, including drilling exploration wells with new play and development wells. Now, most well locations become a populated village and might raise the potential risk to the people and environment. To fulfil safety commitment, well production operations have to be done safely to the people and environment. Currently, there are no specific data that has registered all the wells in Indonesia. This issue is critical for Government and the operating companies to prepare for abandonment waves to prevent methane emissions from abandoned wells. Well Integrity Management, including well registering/database, reporting, risk assessment of trouble wells, and way forward for all the wells, should be initiated by the Government to ensure integrity assurance. It aims to prevent unwanted event in the future, including when the well is permanently abandoned. This paper will present literature studies about international well integrity standards and how well integrity manages the well life cycle. This paper is also providing recommendation to implement Well Integrity Management in Indonesia to ensure end to end well register.
\end{abstract}

\section{INTRODUCTION}

What is well integrity? Why would a well need to be monitored for well integrity throughout its life cycle? When should we perform well integrity inspections? Those are questions that might arise when we discuss well integrity. Some people more familiar with asset integrity term, where well integrity is a significant part of operating company assets (buried vessels - constructed oil/gas wells). Well constructions and maintaining its constructions are process safety. Each step/phase of the operations will have robust processes and systems to manage the integrity of operating systems and processes that handle hazardous substance (Popat et al., 2018).

Some international references regulate well integrity but not limited to:

1. ISO16530-1, Petroleum Natural Gas Well Integrity: Well Integrity for Operational Phase. March 2017.

2. NORSOK D-010, Well Integrity in Drilling \& Well Operations. Rev.4, June 2013.

3. Norsk olije og gass guidelines 117, Well Integrity Guidelines, Rev. 6, November 2017.

4. API RP 65-2, Isolating Potential Flow Zones during Well Construction, 2nd edition, December 2010.

5. API RP 90-2, Annular Casing Pressure Management for Onshore Wells, 1st edition, April 2016.

NORSOK D-010. Rev 4., 2013 define well integrity by application of technical, operational, and organisational solutions to reduce the risk of uncontrolled release of formation fluids throughout the life cycle of a well (ISO - ISO 16530-1:2017 - Petroleum and natural gas industries - Well integrity - Part 1: Life cycle governance, 2017). ISO 16530-1, 2017 define well integrity as containment and the prevention of the escape of fluids (i.e. liquids or gases) to subterranean formations or surface. API RP 652,2010 defines well integrity as a quality or condition of well-being structurally sound with competent 
pressure seals by applying technical, operational, and organisational solutions that reduce the risk of uncontrolled release of formation fluids throughout the well life cycle. In simple words, well integrity is to maintain and ensure that the reservoir fluids are always kept inside the pipe throughout the well life cycles.

Well integrity shall be monitored throughout its life cycle by performing scheduled inspections/maintenance to verify barriers/isolation elements of the buried vessels (wells). It is to ensure that the hazardous materials (hydrocarbons) are kept inside the vessels. This could be done by preparing Well Integrity Management Systems (WIMS) as outlined in ISO 16530-1, 2017 (ISO - ISO 16530-1:2017 - Petroleum and natural gas industries - Well integrity - Part 1: Life cycle governance, 2017). Figure 1 shows the Swiss cheese model. It illustrates different layers of barriers (technical barriers, operational barriers, human barriers, etc.) under a given set of conditions, which can lead to hazards and potential losses. An error may allow the hazard to go thru one layer, but the holes are in the different places for the next layer, and the hazard could be prevented (Hals, 2015).

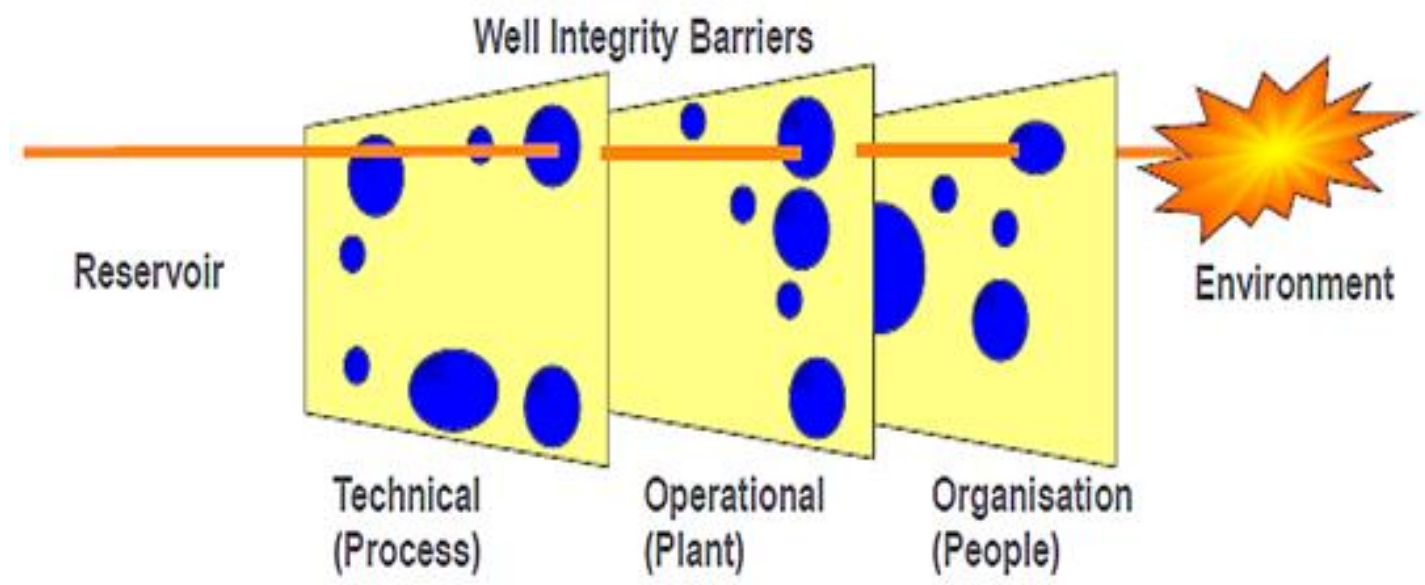

Figure 1. Well Integrity Management System in Swiss cheese model (Gouda \& Aslam, 2018).

In Indonesia, several standards related to well integrity management and strategic well management, but still in a minor scope. It correlates some operations safety in drilling operation, as outlined in SNI 136910-2002; Drilling Operation for Safe Conduct of Onshore and Offshore in Indonesia-Implementation. Due to the complexity of Indonesia's fields, where most of it categorised as old wells, well integrity becoming a major issue as it might risking of losing well production, workover before the planned time, and dangerous to the surrounding area as the reservoir fluid leak to surface (Haris et al., 2012). The most significant impact on well integrity incident is the social impact, environmental impact and losing company reputations (Haris et al., 2012). As assets become mature and older, well integrity problems increase. Risk management becomes intense and increased vigilance. Better surveillance is required to ensure wells and assets are healthy and have a trouble-free operation (Kumar et al., 2014).

Figure 2 shows the well integrity life cycles, which comprises of two main blocks. The first is to ensure asbuilt well integrity (basis of design until well construction phase). The second is to manage well integrity throughout the remaining life after the construction phase, which is the operational and abandonment phase.

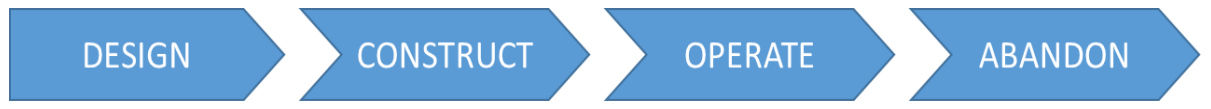

Figure 2. Illustration of well life cycle (Kareem et al., 2015).

Abandoned wells provide a potential pathway for subsurface migration and methane emissions or other fluids to the atmosphere (Kang et al., 2014). Tveit (2018) reviewing the phenomenon of natural hydrocarbon seepages in offshore Norway. The origin of hydrocarbon seepages in Norway could be thermogenic or biogenic (microbial gas). There are no oil seeps in Norway, but several natural gasses leakage in some areas during well life cycle and after abandonment. In the US, mostly in the Gulf of Mexico (Tveit, 2018) and Pennsylvania (Kang et al., 2014), have both oil and gas seepages after abandonment. 
Kang et al. (2014) made methane emissions measurements in 5 plugged wells and shown seepage of methane to the atmosphere. Another challenge for Indonesia is to monitor the abandoned wells to know their integrity to minimise emissions.

This paper's objectives are defining WIMS implementation challenges in Indonesia, addressing minimum required elements for implement WIMS, well-registering process flow, and data evaluation samples from some countries that already implement WIMS. The significance of this paper is to show the proposed improvements and benefits of WIMS implementation to ensure end to end well register to minimise potential leakages (methane emissions) after the end of the life cycle (abandonment).

\section{WELL INTEGRITY STANDARDS}

Literatures reviews on well integrity international standards of ISO 16530-1. 2017, NORSOK D-010 Rev.4, 2013 to know the workflow/algorithm of well integrity is prepared. Indonesia's standards on drilling/operations, including SKK Migas guidance, were also reviewed.

\section{International Well Integrity Standards}

\section{ISO 16530-1}

This standard intended to provide guidelines on managing well integrity throughout the well life cycle to the operating company. It is also to regulate the compliance requirement to claim conformity with this standard. Figure 3 shows the well integrity life cycle as per ISO 16530-1.

There are six stages/phases of well life cycles:

1. Basis of design phase; identify the safety and environmental exposures to surface/subsurface hazards and risks that have to be identified and develop the control method.

2. Design phase; identify the controls incorporated into the well design, with appropriate barriers based on the risks and hazards to people and the environment.

3. Construction phase; identify and define element barriers to be constructed and verification tasks to be performed to assure that the element can be used as a barrier, including handover certificate.

4. Operational phase; define the recommendations and methods well integrity during productions operations.

5. Intervention phase; define minimum requirements for assessing well barriers prior, after and during interventions, including handover certificate.

6. Abandonment phase; define the requirements for permanently abandoning a well.

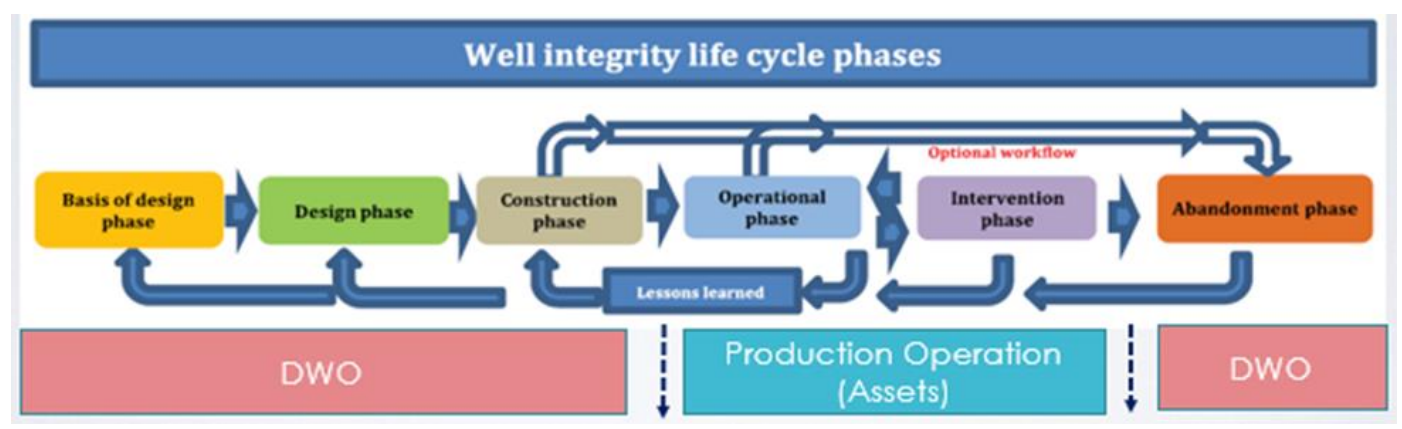

Figure 3. Well Integrity Life Cycle as per ISO 16530-1 (ISO - ISO 16530-1:2017 - Petroleum and natural gas industries - Well integrity - Part 1: Life cycle governance, 2017).

Life cycle phase 1-3 is managed by the drilling and workover team. Phase 4-5 is managed by production operation team. It will return to the drilling and workover team for abandonment if it reaches its production economic limits or faces severe integrity problems.

\section{NORSOK D-010 Rev.4.}

NORSOK D-010, Rev. 4, 2013 focuses on establishing well barriers by using Well Barrier Elements (WBE's); their acceptance criteria, their use and the monitoring of integrity during well life cycle (See Figure 4). Well integrity by defining the minimum functional and performance. This standard provides requirements and guidelines for well design, planning and execution of well activities and operations. 


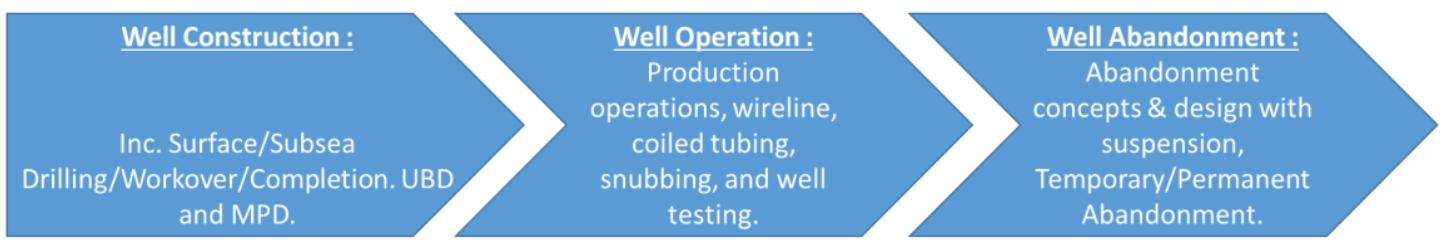

Figure 4. Well Integrity Life Cycle as per NORSOK D-010, Rev.4.

\section{Indonesia's References}

SNI (Standar Nasional Indonesia) 13-6910-2002 for safe conduct in drilling operation implementation defines well integrity in partial for testing/verifications of drilling operations, but not well integrity management or well management.

PTK-041/SKKO0000/2015/S0 - Pedoman Tata Kerja for Production Facility Maintenance defines asset integrity and reliability but does not define well integrity.

PTK-040/SKKMA0000/2018/S0 - Pedoman Tata Kerja for Abandonment and Site Restoration (ASR) also did not define well integrity.

\section{METHODOLOGY}

This paper is literature research by assessing and reviewing several related international standards, journals, papers, and books on well integrity and well life cycle. The results of those various works of literature were compiled, analysed, and used for recommendations and suggestions as part of improvements needed in current Indonesia's well management. All data used was taken from previous papers.

\section{RESULT AND DISCUSSION}

Based on Indonesia's references review, there are challenges to ensure well integrity during well life cycle, especially after the wells have been drilled and handed over to production (Anders et al., 2008). The production phase is the longest phase/period of a well life cycle. A Well Integrity Management (WIM) is recommended to have an overview of wells during the life cycle and prior end of the life cycle (abandonment) to reduce the risks of remediation jobs and methane emissions.

A brief on how to prepare a well integrity management is presented, with data comparison from two oil and gas countries, and way forward for Indonesia's Well Integrity Management Systems.

\section{Well Integrity Management}

Elrefai et al. (2017) and Anders et al. (2008) had explained the benefits of having Well Integrity Management Systems, such as reduced operational cost and fewer well failure, improves process safety, early detection of well failure, preventive maintenance, increased production (by activation/restoring S/I wells), well registering (well-stock status) in detailed/updated status.

Well integrity from both pieces of literature stated about minimum requirements to be implemented, with the following elements:

1. Risk assessment

2. Organisation structure (including roles, responsibilities and competencies)

3. Well barriers philosophy

4. Well barrier element acceptance criteria

5. Reporting and documentation

6. Management of change

7. Continuous improvement

8. Auditing.

Those are elements that need to be socialised and compliance for all Indonesia's operating companies. Some elements will be discussed in details:

\section{Risk Assessment}


The operator shall identify and define the wells' life cycle's well integrity hazards and identify the risk associated with it. The risk register should be established and maintained throughout the well life cycle (Adeyinka et al., 2020).

Prasetya et al. (2018) mentioned the risk assessment application of Oil \& Gas UK Guidelines for the Abandonment of Wells and Standard Nasional Indonesia (SNI) for well with integrity issues. This is a good approach to perform a risk assessment for trouble wells before abandonment. Suppose the operator was implementing well integrity management system beforehand. In that case, the records and documentation of degraded/failure barriers could be determined and mitigated.

\section{Well Barrier Philosophy}

ISO 17776, 2016 define barriers as a measure that reduces the probability of triggering a hazard potential to cause damage or reduces the damage potential. Vignes (2011) define the barrier main function to prevent, control, and reduce losses or mitigate undesired or accidental events. The barriers can also be described as the safety margin, allowing the company to perform petroleum or other activities.

NORSOK D-010, Rev. 4, 2013 define well barrier as an envelope of one or several dependent well barrier elements preventing fluids or gases flowing unintentionally from the formation into another formation or to the surface. The well barriers shall be designed to ensure well integrity during the well's lifetime (called performance-based approach). The well barriers shall be designed to prevent unintended influx and outflow to the external environment and designed to test and verify their performance. Well barriers defined as primary and secondary, as being independent. The primary barrier is the one that is in direct contact with the pressure source to prevent unintended flow. The secondary barrier is and independent redundancy in case the primary failed.

Figure 5 shows the well barrier schematic sample that should be provided to the Government by the operating company for the operational phase.

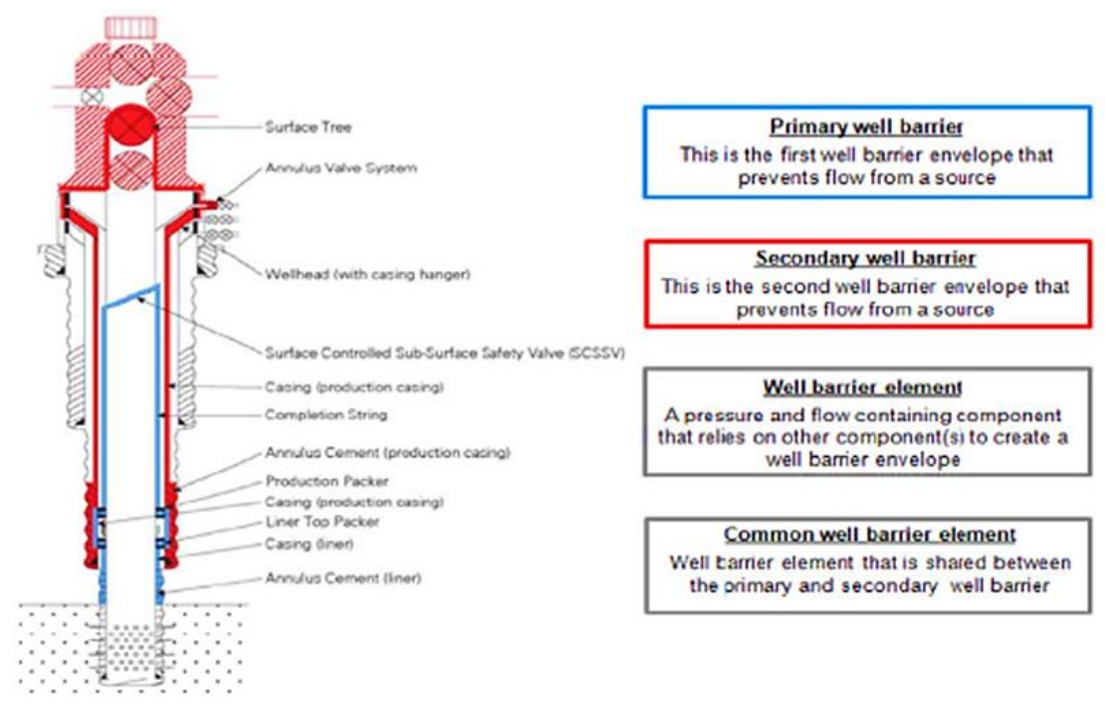

Figure 5. Well barriers schematic (Gouda \& Aslam, 2018).

Based on the barrier philosophy, Well Failure Model (WFM) may be developed and adopted to streamline the risk assessment process, mitigation plan, and response time to repair the failures when they occur. WMF is constructed as a matrix and identifies the most common barrier failures. It would be beneficial if the Government was involved or present during WFM constructions. Also, Government could state the time frame to restore the barrier failure within the time frame. WFM could be referring to Norsk Olje\&Gas-117 (2011) or ISO 16530-1, 2017. Table 1 shows a WFM sample that easy to understand and commonly used by operating companies with weighting method as ISO 16-530-1, 2017 sample. 
Table 1. WFM Sample with weighting method (Mundie et al., 2016)

\begin{tabular}{|c|c|c|c|c|c|c|c|c|c|c|c|c|c|c|}
\hline Code & Description & 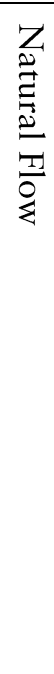 & 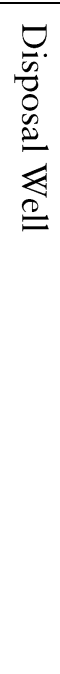 & 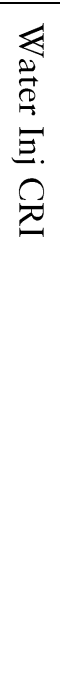 & 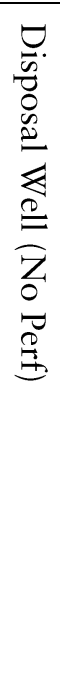 & 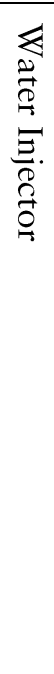 & 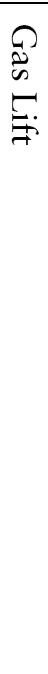 & 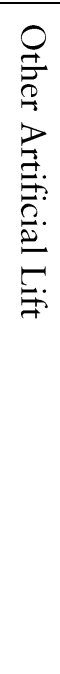 & 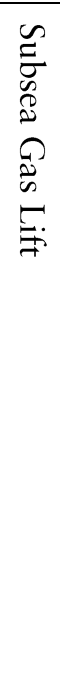 & 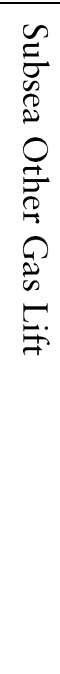 & 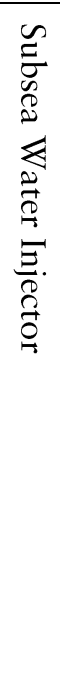 & 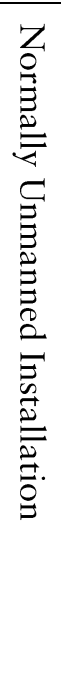 & 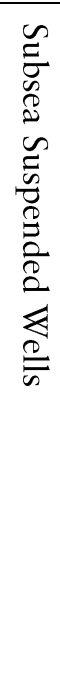 & 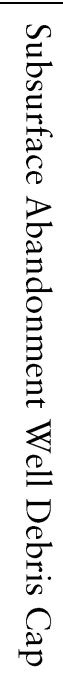 \\
\hline FTT1 & $\begin{array}{l}\text { Failed to carry out WIT } \\
\text { or SIT within advised } \\
\text { allowable time frame - A } \\
\text { Annulus (LH Outer 2), A } \\
\text { Annulus (RH Outer 2), A } \\
\text { Annulus Valve - Left } \\
\text { Inner, A Annulus Valve - } \\
\text { Left Outer, A Annulus } \\
\text { Valve - Right Inner, A } \\
\text { Annulus Valve - Right } \\
\text { Outer, B Annulus Valve- } \\
\text { Left Inner, B Annulus } \\
\text { Valve - Left Outer, B } \\
\text { Annulus Valve - Right } \\
\text { Inner, B Annulus Valve - } \\
\text { Right Outer, C Annulus } \\
\text { Valve - Left Inner, C } \\
\text { Annulus Valve - Left } \\
\text { Outer, C Annulus Valve- } \\
\text { Right Inner, C Annulus } \\
\text { Valve - Right Outer, } \\
\text { Lower Master Valve, } \\
\text { Production Swab Valve, } \\
\text { Production Wing Valve, } \\
\text { Swab Valve, Upper } \\
\text { Master }\end{array}$ & 9 & 9 & 9 & 9 & 9 & 9 & 9 & 9 & 9 & 9 & 9 & & \\
\hline $\begin{array}{l}\text { MS } \\
\text { F1 }\end{array}$ & $\begin{array}{l}\text { S S S V \& Actuated tree } \\
\text { valve } \\
\text { (UMGV/PMV/AMV or } \\
\text { FWV/PWV/AWV) - DHS } \\
\text { V, flow wing valve - } \\
\text { Actuated }\end{array}$ & 9 & 9 & 9 & 9 & 9 & 9 & 9 & 4 & 4 & 4 & 9 & & \\
\hline $\begin{array}{l}\text { MS } \\
\text { F1 }\end{array}$ & $\begin{array}{l}\text { S S S V \& Actuated tree } \\
\text { valve } \\
\text { (UMGV/PMV/AMV or } \\
\text { FWV/PWV/AWV) - } \\
\text { Annulus Wing Valve, } \\
\text { DHS V }\end{array}$ & 9 & 9 & 9 & 9 & 9 & 9 & 9 & 4 & 4 & 4 & 9 & & \\
\hline $\begin{array}{l}\text { MS } \\
\text { F1 }\end{array}$ & $\begin{array}{l}\text { S S S V \& Actuated tree } \\
\text { valve }\end{array}$ & 9 & 9 & 9 & 9 & 9 & 9 & 9 & 4 & 4 & 4 & 9 & & \\
\hline
\end{tabular}




\begin{tabular}{|c|c|c|c|c|c|c|c|c|c|c|c|c|}
\hline & $\begin{array}{l}\text { (UMGV/PMV/AMV or } \\
\text { FWV/PWV/AWV) - DHS } \\
\text { V, Upper Production } \\
\text { Master Valve }\end{array}$ & & & & & & & & & & & \\
\hline $\begin{array}{l}\text { MS } \\
\text { F1 }\end{array}$ & $\begin{array}{l}\text { S S S V \& Actuated tree } \\
\text { valve } \\
\text { (UMGV/PMV/AMV or } \\
\text { FWV/PWV/AWV) - DHS } \\
\text { V, Flow Wing Valve - } \\
\text { Manual }\end{array}$ & 9 & 9 & 9 & 9 & 9 & 9 & 9 & 4 & 4 & 4 & 9 \\
\hline $\begin{array}{l}\text { MS } \\
\text { F1 }\end{array}$ & $\begin{array}{l}\text { S S S V \& Actuated tree } \\
\text { valve (UMGV/P MV/A } \\
\text { MV or FWV/PWV/AWV) } \\
\text { - DHS V, Upper Master } \\
\text { Valve }\end{array}$ & 9 & 9 & 9 & 9 & 9 & 9 & 9 & 4 & 4 & 4 & 9 \\
\hline $\begin{array}{l}\text { MS } \\
\text { F1 }\end{array}$ & $\begin{array}{l}\text { S S S V \& Actuated tree } \\
\text { valve } \\
\text { (UMGV/PMV/AMV or } \\
\text { FWV/PWV/AWV) } \\
\text { Annulus Master Valve - } \\
\text { DHS V }\end{array}$ & 9 & 9 & 9 & 9 & 9 & 9 & 9 & 4 & 4 & 4 & 9 \\
\hline $\begin{array}{l}\text { MS } \\
\text { F10 }\end{array}$ & $\begin{array}{l}\text { Multiple Annulus } \\
\text { Valve/VR plug failure on } \\
\text { A Annulus or lift } \\
\text { Annulus, Gas lift wells, } \\
\text { see A Annulus Valve - } \\
\text { Left Inner, A Annulus } \\
\text { Valve-Left Outer }\end{array}$ & 5 & 5 & 6 & 6 & 8 & 4 & & & & & 5 \\
\hline $\begin{array}{l}\text { MS } \\
\text { F10 }\end{array}$ & $\begin{array}{l}\text { Multiple Annulus } \\
\text { Valve/VR plug failure on } \\
\text { A Annulus or lift } \\
\text { Annulus, Gas lift wells, } \\
\text { see A Annulus Valve - } \\
\text { Right Inner, A Annulus } \\
\text { Valve - Right Outer }\end{array}$ & 5 & 5 & 6 & 6 & 8 & 4 & & & & & 5 \\
\hline $\begin{array}{l}\text { MS } \\
\text { F2 }\end{array}$ & $\begin{array}{l}\text { S S S V \&LMGV or Swab } \\
\text { or KWV failure - DHS V, } \\
\text { Swab valve }\end{array}$ & 6 & 6 & 6 & 6 & 6 & 5 & 3 & 3 & 3 & 3 & 5 \\
\hline
\end{tabular}

\section{Well Barrier - Element Acceptance Criteria (EAC)}

Acceptance criteria for all well components that act as barriers, including their selection criteria, monitoring, and verification, are followed. Each element (barrier) shall be defined with acceptance criteria to qualify as a barrier and create a barrier envelope.

Each well reported having specific verification as outlined in Element Acceptance Criteria (EAC) tables in NORSOK D-010, Rev. 4, 2013. There are $59 \mathrm{EAC}$ at the moment, with 1 EAC empty for the upcoming barrier element. EAC from NORSOK has acknowledged the new technologies in drilling operation, the use of Rotating Circulating Device (RCD), Downhole Isolation Valve (DIV) and Managed Pressure Drilling (MPD) to convey drilling complexity operation where severe, total and immediate circulation losses are encountered as mentioned by Darmawan et al. (2011)

Table 2 shows one sample of well EAC for wireline lubricator as a barrier, where it consists of description, function, design/construction/selection, initial test/verification, use and monitoring 
Table 2. An example of Table 44-Wireline Lubricator of Well Barrier Element Acceptance Criteria (EAC) (NORSOK D-010:2013, 2013).

\begin{tabular}{|c|c|c|}
\hline Features & Acceptance Criteria & See \\
\hline Description & $\begin{array}{l}\text { This element consists of a body with a lubricator } \\
\text { connection in both ends }\end{array}$ & \\
\hline Function & $\begin{array}{l}\text { The function is to provide lubricate space for } \\
\text { BHA over the closing device when run into and } \\
\text { out of well }\end{array}$ & \\
\hline $\begin{array}{l}\text { Design, construction, } \\
\text { and material selection }\end{array}$ & $\begin{array}{l}\text { The WL lubricator shall be constructed following } \\
\text { NORSOK D-002. }\end{array}$ & $\begin{array}{l}\text { See NORSOK D- } \\
002\end{array}$ \\
\hline $\begin{array}{l}\text { Initial test and } \\
\text { verification }\end{array}$ & $\begin{array}{l}\text { 1. Function test after installation } \\
\text { 2. Perform low and high-pressure leak tests } \\
\text { after initial installation. } \\
\text { 3. Leak test connections where seals have } \\
\text { been de-energised to maximum WHP on } \\
\text { following runs }\end{array}$ & \\
\hline Use & $\begin{array}{l}\text { The total length of lubricators shall allow } \\
\text { sufficient height above the upper well closing } \\
\text { device to contain the complete tool string, } \\
\text { including items pulled from the well. }\end{array}$ & \\
\hline Monitoring & Visual periodic inspection & \\
\hline Common Well Barrier & None & \\
\hline
\end{tabular}

\section{Reporting \& Documentation}

Data related to well design, construction, operation, maintenance and permanent abandonment should be maintained and accessible throughout the well life cycle (ISO - ISO 16530-1:2017 - Petroleum and natural gas industries - Well integrity - Part 1: Life cycle governance, 2017). The well barrier element degradation/leak dictated the well status, which also needs to be documented, including any operation/maintenance to restore the barriers.

\section{Continuous Improvement}

As part of well design feedback, operational feedback, and maintenance feedback to improve the design and operation effectiveness.

\section{Auditing}

Government and operating companies should perform audits in well integrity management to ensure compliances. Short terms and long terms finding actions is documented.

\section{Well Registering}

The operating companies and Government should register the wells that already existed and prepare the upcoming drilled wells. Total wells quantity/population in Indonesia is always in a big question mark. No specific data was found to quantify how many wells were abandoned and how many wells were producing. Registering and clustering the wells across the country is critical to prepare for abandoned waves in Indonesia. Figure 6 shows the well registering process.

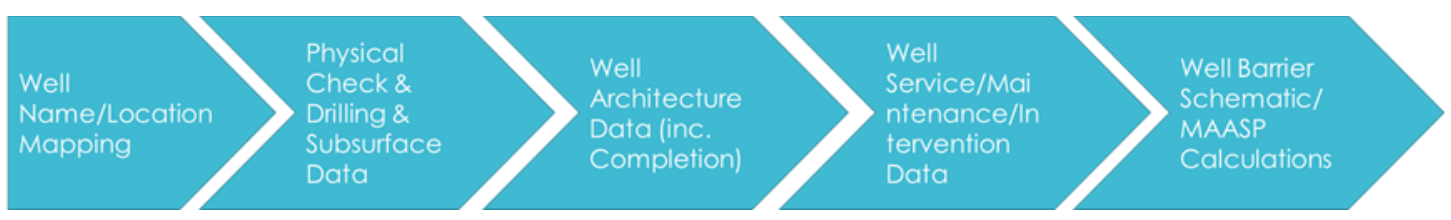

Figure 6. Well registering process

\section{Well Integrity Management Case Results (WIMS)}

Gouda \& Aslam (2018) stated that the outcome of WIMS throughout well life cycle had reduced the numbers of unhealthy wells significantly over the years. 
Gouda \& Aslam (2018) stated that Algeria already implements well integrity status of each field within the country was reported and monitored quarterly with excellent improvement on producer wells. Figure 7 shows the decrease of trouble wells/unhealthy wells because each operating company was urge to comply to well integrity.

There is no monitoring on abandoned wells in both countries to ensure no methane emissions caused by it once the well comes to the abandonment phase.

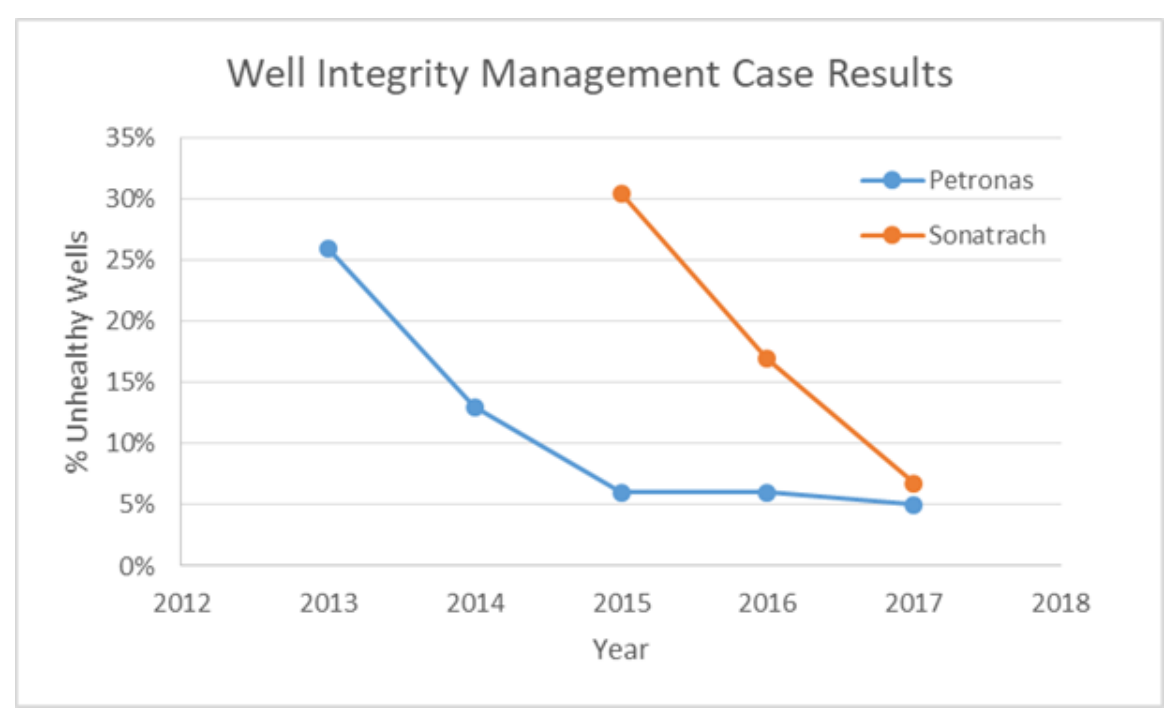

Figure 7. WIMS implementation in Malaysia and Algeria has shown improvement in healthy wells.

\section{SUMMARY FOR WELL INTEGRITY MANAGEMENT IN INDONESIA}

Based on the literature review above, well integrity management needs to be developed to make a database of drilled/produced/abandoned wells all over Indonesia in term of well register and well life cycle. There are challenges in developing and implementing well integrity management in Indonesia, such as:

1. Well registering/populating, no specific data on total well quantity.

2. Integrity issues on produced, injected, suspended, temporary abandoned, and permanent abandoned were not properly addressed, monitored, or even documented.

3. Vast variety of well constructions model that needed to be carefully addressed.

4. Populated area in onshore fields

5. Prescriptive abandonment approach that may increase the risk of methane emission in the future.

Well registering is a fundamental step in acquiring well quantity database, followed by WIMS and continuous monitoring on trouble/unhealthy wells during well life cycle to reduce the risk of leakages. Recommended steps to prepare implementation for well integrity management in Indonesia:

1. Develop an organisation body (could be under SKK Migas or Ditjen Migas)

2. Develop a Well Integrity / Well Management policy

3. Define the rules (barriers/safety-critical elements/EAC-element acceptance criteria) with well failure model

4. Prepare well barrier diagrams for all type of wells operation production and abandonment phase.

5. Reporting from all operating companies every six months with short term and long term plans for the trouble wells. Six months of reporting gives the operators enough time to restore the integrity issues in the trouble wells.

6. Risk assessment prior to any well barrier restoration plans.

7. Final well barrier diagram (as of build-in abandonment barrier diagram).

Well integrity management for each of well life cycle relies on risk level As Low as Reasonably Practical (ALARP). For a start, well integrity only manage wells that have been constructed, even though not yet produced, to have full monitoring of Indonesia's well assets. Figure 8 shows the flowchart of proposed well integrity management: 
Improvement on Well Management for Well Life Cycle

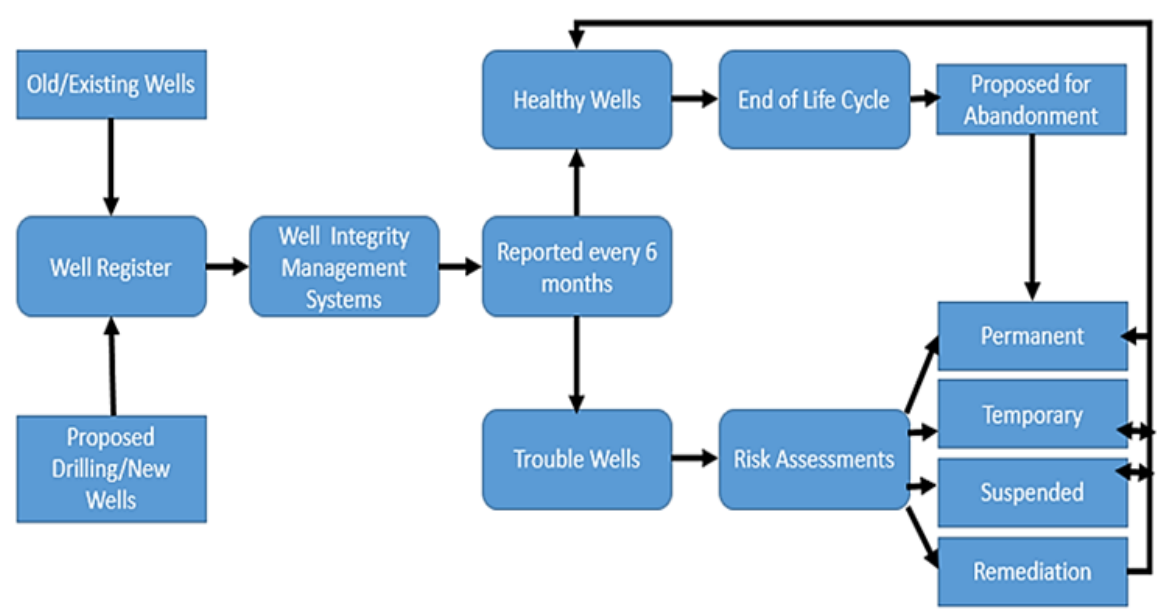

Figure 8. Proposed Well Integrity Management in Indonesia.

Well integrity management could be useful tools to be implemented rather than firefighting because of well leaks or abandonment well leaks which release gas to the surface on a populated area. This effort could save the people, environment and reputation.

These efforts could save the government time in assessing proposed permanent abandonment. Hence, the Government has the right to ask the operator to suspend or abandon a well based on the trouble wells' risk assessment report. In Indonesia, there are local Government who wanted to operate the old wells traditionally. By having accurate and complete well integrity data for all wells, the Government can choose the safe and healthy wells to be transferred and abandoned the rest to avoid future leakage issues. Well integrity data dictate the complexity of abandonment design and operation, hence preferable to have all operators comply with well integrity standard for a better well database as integral part of the well life cycle in the abandonment phase.

\section{CONCLUSION}

Well integrity management implementation has significantly improved the numbers of healthy wells, reducing the risk of abandonment leakage at the end of well life cycle. Indonesia's Government has the main role play in preparing the policy, well failure models and well barrier diagrams followed with reporting on operator well integrity status. Development and implementation of Well Integrity Management (WIM) for all operators in Indonesia will bring clearer pictures of the trouble wells populations and could be risk assessed carefully during the operational phase, prior to temporary or permanently abandoned to minimise methane emissions.

\section{ACKNOWLEDGEMENTS}

The author would like to acknowledge the support of the Petroleum Engineering Department, Bandung Institute of Science Technology.

\section{REFERENCES}

Adeyinka, A., Tsakporhore, A., Arije, O., Adegoke, O., Aliyev, S., Iwueze, C., \& Hulett, R. (2020, August 11). Rethinking well integrity for sustainability: Adopting a risk based approach. Society of Petroleum Engineers - SPE Nigeria Annual International Conference and Exhibition 2020, NAIC 2020. https://doi.org/10.2118/203672-ms

Anders, J., Rossberg, S., Dube, A., Engel, H., \& Andrews, D. (2008). Well integrity operations at Prudhoe Bay, Alaska. SPE Production and Operations, 23(2), 280-286. https://doi.org/10.2118/102524-pa

Darmawan, G. R., Susilo, S. D., \& Toralde, J. S. S. (2011). Successful installation and operation of downhole isolation valve combined with pressurized mud cap drilling to safely develop sour gas, fractured-limestone reservoir in Gundih Field, Indonesia. International Conference on Health, Safety and Environment in Oil and Gas Exploration and Production, 100-109.

Elrefai, M. A., Al Mutairi, A. M., Al Saadi, M., Nasser, F., Abdi, R. M., ALQamzi, A., AlNaqbi, M. A., \& Ashgar, A. (2017). Inhouse design and implementation of well integrity database management system. Society of Petroleum Engineers - SPE Abu Dhabi International Petroleum Exhibition and Conference 2017, 2017-Janua. https://doi.org/10.2118/188726-ms 
Gouda, M. H., \& Aslam, I. (2018). Well integrity life cycle. Society of Petroleum Engineers - SPE International Conference and Exhibition on Health, Safety, Security, Environment, and Social Responsibility 2018. https://doi.org/10.2118/190504-ms

Hals, A. (2015). Well Integrity Assessment: Challenges related to Human and Organizational Factors-The case study of Veslefrikk. NTNU.

Haris, A., Purwanto, B., Sasongko, D., Darmawan, G. R., Yulianto, I., Soekmono, O., Kurniawan, P., Susilo, S. D., Kurniawan, S., \& Mailangkay, L. (2012). Workover and completion operations in East Java sour gas field, Indonesia. Society of Petroleum Engineers - SPE/APPEA Int. Conference on Health, Safety and Environment in Oil and Gas Exploration and Production 2012: Protecting People and the Environment - Evolving Challenges, 1, 45-52. https://doi.org/10.2118/153090-ms

ISO - ISO 16530-1:2017 - Petroleum and natural gas industries - Well integrity - Part 1: Life cycle governance. (2017).

Kang, M., Kanno, C. M., Reid, M. C., Zhang, X., Mauzerall, D. L., Celia, M. A., Chen, Y., \& Onstott, T. C. (2014). Direct measurements of methane emissions from abandoned oil and gas wells in Pennsylvania. Proceedings of the National Academy of Sciences of the United States of America, 111(51), 18173-18177. https://doi.org/10.1073/pnas.1408315111

Kareem, H., Ali, A. J., Zahra, M. A., \& Al-Ibraheemi, A. T. (2015). Restoring and managing brownfield wells integrity to operate safely and reliably in South of Iraq. Society of Petroleum Engineers - Abu Dhabi International Petroleum Exhibition and Conference, ADIPEC 2015. https://doi.org/10.2118/177885-ms

Kumar, S., Al-Atwi, M. A., Al-Mulhim, A. K., Al-Otaibi, M. A., Al-Mulhim, M. S., \& Ali, A. T. B. (2014). Inching toward complete well integrity management. Society of Petroleum Engineers - SPE International Conference and Exhibition on Oilfield Corrosion 2014: New Challenges for a New Era, 86-94. https://doi.org/10.2118/169607-ms

Mundie, G., Wilson, S., \& Copping, S. (2016). Data to language - Leveraging software to understanding and communicate well integrity risk throughout the organisation. Society of Petroleum Engineers SPE Intelligent Energy International Conference and Exhibition. https://doi.org/10.2118/181054-ms

NORSOK D-010:2013. (2013). Well integrity in drilling and well operations. Rev. 4, June 2013. In Standards Norway, Rev (Vol. 4, p. 224).

Popat, N., Perkins, B., Vassiliev, N., Reyes Valdes, O., Hawkes, C., \& Carvalho, M. (2018). Development, adoption and implementation of fabrication site construction safety recommended practices. Society of Petroleum Engineers - SPE International Conference and Exhibition on Health, Safety, Security, Environment, and Social Responsibility 2018. https://doi.org/10.2118/190581-ms

Prasetya, A. E., Rakhmahwidiati, R., \& Hutabarat, R. D. P. (2018, December 3). Plug and Abandonment Procedures for Onshore Wells and the Utilization of Reserved Abandonment and Site Restoration ASR Funds. Day 1 Mon, December 03, 2018. https://doi.org/10.2118/193956-MS

Tveit, M. R. (2018). Understanding Leakage Rates in Permanently Abandoned Wells by Studying Natural Hydrocarbon Seepages. University of Stavanger, Norway.

Vignes, B. (2011). Contribution to well integrity and increased focus on well barriers from a life cycle aspect. 